\title{
Geo-ecological interaction: Community based forest management in Karanganyar, Indonesia
}

\author{
Alan Sigit Fibrianto* \& Ananda Dwitha Yuniar \\ Departmen of Sociology, Faculty of Social Sciences, Universitas Negeri Malang, Indonesia \\ Ifan Deffinika \\ Department of Geography, Faculty of Social Sciences, Universitas Negeri Malang, Indonesia \\ Aulia Azzardina \\ Department of Accounting, Faculty of Economics, Universitas Negeri Malang, Indonesia \\ Dina Afrianty \\ La Trobe University, Melbourne, Australia
}

\begin{abstract}
This study aimed to describe the social life of forest village communities and their participation in LMDH attachments. This research used a geo-ecological approach with a case study qualitative method to describe the relationship between the local com-munity with LMDH, located in Tambak Hamlet, Berjo Village, Ngargoyoso District, Ka-ranganyar Regency. This study uses primary and secondary data. Preliminary data was collected through in-depth interviews, while secondary data was obtained from village monographs. The results show that the management and utilization of forest resources are still thick with local wisdom, such as traditions and rituals. Social and economic character-istics are closely related to geographical conditions. Irrigated agriculture is the dominant activity in the agricultural sector. The use of agricultural land is very suitable for the suita-bility of the ground there. The embededdness between LMDH and the people of Tambak Hamlet, Berjo Village, is at the level of the programs established by LMDH following the characteristics of natural processing and daily community activities.
\end{abstract}

Keywords: ecology, forest, management

\section{INTRODUCTION}

National and regional development cannot be separated from village development activi-ties, in its implementation there is nothing that is not feeling the development or can be called "No-one left behind" (CNBC Indonesia 2020; Deswimar 2014; Rahayu 2017; Némethová 2020; Payne 2018; Saberifar \& Mishrab 2020; Afifuddin 2010; Akbar et al. 2019; Mardhiah 2017; Bappenas 2020; Hermayana 2019; Khairuddin 2000; Siswijono 2008; ICCTF 2020). Community-driven development is the development of the concept of people-centered development. The existence of this concept is a reaction to the existing development concepts in economic growth. This concept is a form of social plan-ning to carry out planned social changes, namely, change the community's attitudes and social behavior so that they can become empowered and able to carry out development in their environment (Sitorus 2017; Haryanto 2012; Zaenudin et al. 2014; Birgantoro \& Nurrochmat 2007; Arifandy \& Sihaloho 2015; Theresia et al. 2014; Siagian 2005; Adisasmita 2006; Marbun 1983). Adimihardja and Hikmat (2003) state that a product must come from the community itself,

*Corresponding author: alan.sigit.fis@um.ac.id 
including a village's development (Sumbi \& Firdausi 2016). One type of development carried out by the government in rural areas is establishing the Forest Village Community Institution, or in Indonesia, it is called 'Lembaga Masyarakat Desa Hutan/ LMDH'. LMDH was formed to increase a sense of concern for the forest by not cutting forests carelessly. The establishment of the LMDH in Berjo Village is sharing roles, shar-ing space and time, and sharing results. By involving village communities in forest man-agement, planning, implementation, monitoring, and evaluation will give them deep mean-ing. The mission or activity carried out by LMDH in Tambak Hamlet, Berjo Village, Ngar-goyoso District, Karanganyar Regency is to optimize forest use by managing forests as fruit plantations, the potential for educational tourism, and citronella oil refining. Howev-er, the obstacles faced are the people of Tambak Hamlet, Berjo Village, Ngargoyoso Dis-trict, Karanganyar Regency, most of whom do not know and understand the function of LMDH itself. Therefore, this research's title is "Geo-ecological Interaction: Community Based Forest Management in Karanganyar, Indonesia." Based on the background of the problem above, the formulation of the situation in this study is how the community's life and the closeness between LMDH and the community in Tambak Hamlet, Berjo Village, Ngargoyoso District, Karanganyar Regency?

\section{METHODS}

This research used a geo-ecological approach with a case study qualitative method to de-scribe the relationship between the local community with LMDH, located in Tambak Ham-let, Berjo Village, Ngargoyoso District, Karanganyar Regency. This study uses primary and secondary data. Preliminary data was collected through in-depth interviews, while second-ary data was obtained from village monographs (Salim 2006; Miles \& Huberman 1992; Moleong 2007).

\section{RESULTS AND DISCUSSION}

Berjo Village is one of the villages located in Ngargoyoso District, Karanganyar Regency. The town with an area of 1,623,865 hectares is located on the lower slopes of Mount Lawu. When viewed based on the topography, this village is at an altitude of \pm 800 masl and has a tropical climate with an average temperature of $\pm 22^{\circ} \mathrm{C}-32^{\circ} \mathrm{C}$. Girimulyo Vil-lage borders the northern part of Berjo Village; in the east, it is bordered by Mount Lawu forest, the west is bordered by Puntukrejo Village, and to the south, it is bordered by Ta-wangmangu District. The total population in Berjo Village is 5,551 people or $16 \%$ of the total population in the Ngargoyoso District. The community of productive age in this vil-lage is 3,741 people. The majority of the population in Berjo Village have a livelihood as farmers and farm laborers. As many as $85 \%$ of the total population in this village work as farmers and farm laborers. The second-largest livelihood after farmers is construction or industrial workers, which is $6 \%$, and traders occupy the third position with a total of $4 \%$ of the population. The large number of residents who work as farmers and farm laborers is closely related to the geographical conditions of Tambak Hamlet, Berjo Village, Ngar-goyoso District, Karanganyar Regency as one of the villages with high soil fertility poten-tial. It can be seen in Figure 2 that $84 \mathrm{Ha}$ or $5 \%$ of the land in this village is rice fields, $92 \mathrm{Ha}$ or $6 \%$ of the total area of Berjo Village is a built-up area (settlement), $191 \mathrm{Ha}$ or $12 \%$ of the total land area is used as Plantation land, 1,236 Ha or $76 \%$ of the whole earth is forest, and $20.87 \mathrm{Ha}$ is another land use. The potential for high soil fertility is utilized by carrying out economic activities in the agricultural sector. Data from BPS (2019) states that around $57 \%$ of the land area in Ngargoyoso District is used for rice fields. Berjo is one of the villages that use its land to dominate simple irrigated rice field farming activities. As for the community's economic activities, which in this case, are farmers, apply a subsist-ence economy as their survival strategy. The purpose of a subsistence economy is an agri-cultural financial system by consuming its agricultural products as a fulfillment of daily needs. Berjo Village, Ngargoyoso District, Karanganyar Regency is a village where most of its territory is a forest under Mount Lawu. The existence of natural resources in the form of woods with an area of 1,236 hectares or 
$76 \%$ of the total area of Berjo Village is managed by the surrounding community so that they can be utilized optimally. In terms of forest management, there are three main parties, namely Tamah Hutan Raya, the Indone-sian State Forest Company (Perhutani), and the Forest Village Community Institution (LDMH) (Setiyawan 2019).

The field findings show that the people of Berjo Village have an economic pattern as veg-etable farmers. In contrast, the primary source of income is then supported by several side economic activities and a form of investment in the form of livestock. The vegetable farming community pattern that has existed for a long time is not necessarily the only sec-tor that is highlighted by the people of Tambak Hamlet; there are several parts of life that link the community to their economic system. Several sectors of people's life are indirectly related to their economic system. Thoughts on the economy have many variations of con-cepts; the concept of embeddedness, coined by Marc Granovetter, sees the financial sys-tem as closely related to various external things, such as values and norms, networks where These social relations build the economic system in it. Granovetter's study sees that the economic system will not be separated from the various social relations around it (Granovetter 1985; Swedberg 2003; Blikololong 2012; Chalid 2011; Haryanto 2011). Like in Tambak Hamlet, their economic activities as garden farmers are not only about planting in the fields and producing crops at a particular time, but several things affect the progress of their economic cycle, their welfare, the wealth they have, how to manage their wealth. And others. Some of the dimensions used to study the financial organization of Tambak Hamlet include the leading economy, path dependency, investment, ownership, valuation, and trust. Each of these things has a relationship with the people's lives, using Granovetter's frame of mind to explain that these things have a relationship or attachment to people's lives, so the economic organization there will continue to run and survive. The extension of financial organizations to society will cause a slice or intersection, which causes the two things to have part of one another.

\section{CONCLUSION}

The embeddedness between the community and the LMDH is at the program level estab-lished by the LMDH because these programs have natural processing characteristics, espe-cially village forests, by the community's daily activities, so it does not require long ad-justments to realize LMDH programs. Analysis of the life of the people of Tambak Ham-let, among others: (a) The community economy; (b) Community investment; (c) Commu-nity ownership; (d) Valuation in society; (e) People's beliefs; and (f) Leadership in the community

\section{REFERENCES}

Adisasmita, R., 2006. Pembangunan pedesaan dan perkotaan, Graha Ilmu.

Afifuddin, 2010. Pengantar Administrasi Pembangunan, Bandung: Alfabeta.

Akbar, G.G., Hermawan, Y. \& Karlina, A.L., 2019. Analisis Perencanaan Pembangunan Desa Di Desa Sukamaju Kecamatan Cilawu Kabupaten Garut. Jurnal Pembangunan dan Kebijakan Publik, 10(2), pp. 1-8.

Arifandy, M.I. \& Sihaloho, M., 2015. Efektivitas pengelolaan hutan bersama masyarakat sebagai resolusi konflik sumber daya hutan. Sodality: Jurnal Sosiologi Pedesaan, Agustus.

Bappenas, 2020. "Apa Itu SDGs.” Available at: http://sdgsindonesia.or.id/.

Birgantoro, B.A. \& Nurrochmat, D.R., 2007. Pemanfaatan Sumberdaya Hutan oleh Masyarakat di KPH Banyuwangi Utara. Jurnal Manajemen Hutan Tropika, 13(3), pp. 172-181.

Blikololong, J.B., 2012. Evolusi Konsep Embeddedness dalam Sosiologi Ekonomi (Sebuah Review). UG Jurnal, 6(12), pp. 23-29.

Chalid, P., 2011. Sosiologi Ekonomi, Jakarta: Universitas Terbuka.

CNBC, I., "No One Left Behind Untuk Kesejahteraan Masyarakat.” Available at: https:/www.cnbcindonesia. com/market/20200713134319-19-172238/no-one- left-behind-untuk -kesejahteraan-masyarakat.

Devi Deswimar, A., 2014. PERAN PROGRAM PEMBERDAYAAN MASYARAKAT DESA DALAM PEMBANGUNAN PEDESAAN. Jurnal EL-RIYASAH, 5(1), p. 41. 
Granovetter, M., 1985. Economic action and social structure: The problem of embeddedness. American journal of sociology, 91(3), pp. 481-510.

Haryanto, S., 2011. Sosiologi ekonomi. Yogyakarta: Ar-Ruzz Media.

Haryanto, T.D., 2012. Pengelolaan Sumberdaya Hutan Bersama Masyarakat Dalam Sistem Agroforestry. Wacana Hukum, 10(1), pp. 17-30.

Hermayana, 2019. "Peran Milenial Menyongsong SDGs (Sustainable Development Goals).” Kompasiana.

ICCTF, 2020. "Tentang SDGs."

Khairuddin, 2000. Pembangunan Masyarakat, Yogyakarta: Liberty.

Marbun, B.., 1983. Proses Pembangunan Desa, Jakarta: Erlangga.

Mardhiah, N., 2017. IDENTIFIKASI TUJUAN DAN SASARAN PEMBANGUNAN DESA KABUPATEN ACEH BARAT. Jurnal Public Policy.

Miles, M.B. dan H.A.M., 1992. Analisa Data Kualitatif, Jakarta: UI Press.

Moleong, L., 2007. Metodologi Penelitian Kualitatif, Bandung: PT Remaja Rosdakarya.

Némethová, J., 2020. Comparison of implementation of rural development programmes focussing on diversification in Slovakia in the years 2007-2013 and 2014-2020. Folia Geographica, 62(1), pp. 35-51.

Payne, M.I., 2018. Slovak Roma Village of Origin and Educational Outcomes: A Critical Evaluation. Folia Geographica, 60(1), pp. 31-49.

Rahayu, D., 2017. Strategi Pengelolaan Dana Desa untuk Meningkatkan Kesejahteraan Masyarakat Desa Kalikayen Kabupaten Semarang. Economics Development Analysis Journal, 6(2), pp. 107-116.

Saberifar, R. \& Mishrab, P.K., 2020. Analysis of National Development Using Labour Market Model: A Case Study of Khaf. Folia Geographica, 1(62), pp. 5-20.

Salim, A., 2006. Teori \& Paradigma Penelitian Sosial. Yogyakarta: Tiara Wacana, p. 6.

Setiyawan, K.B., 2019. "Modal Sosial dalam Pengelolaan Hutan Rayat: Studi Kasus di Desa Berjo Ngargoyoso Karanganyar Jawa Tengah.” Jurnal Sosial Ekonomi Pertanian, 15(2), pp. 156-63.

Siagian, S.P., 2005. Organisasi Kepemimpinan dan Perilaku Administrasi, Cetakan Pertama, PT. Gunung Agung, Jakarta.

Siswijono, Bambang, dan Wisadirana, D., 2008. Sosiologi Pedesaan dan Perkotaan, Malang: Agritek YPN.

Sitorus, Y.L.M., 2017. Community Driven Development In Traditional Communities In Papua. Journal of Regional and City Planning, 28(1), pp. 16-31.

Sumbi, K. \& Firdausi, F., 2016. Analisis Pembangunan Berbasis Masyarakat dalam Pengembangan Sumber Daya Masyarakat. Jisip: Jurnal Ilmu Sosial dan Ilmu Politik, 5(2).

Swedberg, R., 2003. Principles of Economic Sociology, United Kingdom: Princeton University Press.

Theresia, A. et al., 2014. Pembangunan berbasis masyarakat: acuan bagi praktisi, akademisi, dan pemerhati pengembangan masyarakat, Penerbit Alfabeta.

Zaenudin, Dundin, Anang Hidayat, and T.L., 2014. "Pengelolaan Hutan Berbasis Masyarakat,” Polict Brief 02 LIPI. 